Article

\title{
Shortening the Vegetative Growth Stage of Phalaenopsis Queen Beer 'Mantefon' by Controlling Light with Calcium Ammonium Nitrate Levels under Enriched $\mathrm{CO}_{2}$
}

\author{
Ah Ram Cho, Sun Woo Chung ${ }^{+}(\mathbb{D})$ and Yoon Jin Kim * (D) \\ Department of Horticulture, Biotechnology and Landscape Architecture, Seoul Women's University, \\ Seoul 01797, Korea; ar092@swu.ac.kr (A.R.C.); jsw599@korea.kr (S.W.C.) \\ * Correspondence: yj1082@swu.ac.kr; Tel.: +82-2-970-5614 \\ + Current address: Research Institute of Climate Change and Agriculture, National Institute of Horticultural and \\ Herbal Science, Rural Development Administration, Jeju 63240, Korea.
}

check for

updates

Citation: Cho, A.R.; Chung, S.W.;

Kim, Y.J. Shortening the Vegetative Growth Stage of Phalaenopsis Queen Beer 'Mantefon' by Controlling Light with Calcium Ammonium Nitrate Levels under Enriched $\mathrm{CO}_{2}$.

Horticulturae 2022, 8, 157.

https://doi.org/10.3390/

horticulturae8020157

Academic Editor: Jiafu Jiang

Received: 10 December 2021

Accepted: 9 February 2022

Published: 11 February 2022

Publisher's Note: MDPI stays neutral with regard to jurisdictional claims in published maps and institutional affiliations.

Copyright: (C) 2022 by the authors. Licensee MDPI, Basel, Switzerland. This article is an open access article distributed under the terms and conditions of the Creative Commons Attribution (CC BY) license (https:// creativecommons.org/licenses/by/ $4.0 /)$.

\begin{abstract}
The vegetative growth, photosynthetic, and stomatal characteristics were investigated in Phalaenopsis Queen Beer 'Mantefon' to determine light's influence with calcium ammonium nitrate (CAN) levels under $800 \mu \mathrm{mol} \cdot \mathrm{mol}^{-1} \mathrm{CO}_{2}$. Two lights $\left(150 \pm 20\right.$ and $\left.300 \pm 20 \mu \mathrm{mol} \cdot \mathrm{m}^{-2} \cdot \mathrm{s}^{-1}\right)$ and CAN levels were employed for 40 weeks: calcium, ammonium, and nitrate levels by 0.90, 0.55, and $2.97 \mathrm{mmol} \cdot \mathrm{L}^{-1}$ (CAN1), 8.63, 1.11, and $6.05 \mathrm{mmol} \cdot \mathrm{L}^{-1}$ (CAN2), 12.80, 1.72, and $9.13 \mathrm{mmol} \cdot \mathrm{L}^{-1}$ (CAN3), and 18.80, 2.27, and $12.20 \mathrm{mmol} \cdot \mathrm{L}^{-1}$ (CAN4), respectively. The number of leaves increased in the plants grown at $300 \pm 20 \mu \mathrm{mol} \cdot \mathrm{m}^{-2} \cdot \mathrm{s}^{-1}$ with CAN1 compared to control. Plants grown at $300 \pm 20 \mu \mathrm{mol} \cdot \mathrm{m}^{-2} \cdot \mathrm{s}^{-1}$ with CAN4 had the lowest number of leaves among all plants. The time to the mature leaf span decreased in the plants grown at $300 \pm 20 \mu \mathrm{mol} \cdot \mathrm{m}^{-2} \cdot \mathrm{s}^{-1}$ with CAN1. The net $\mathrm{CO}_{2}$ uptake was higher in the plants grown at $300 \pm 20 \mu \mathrm{mol} \cdot \mathrm{m}^{-2} \cdot \mathrm{s}^{-1}$ than those grown at $150 \pm 20 \mu \mathrm{mol} \cdot \mathrm{m}^{-2} \cdot \mathrm{s}^{-1}$ with CAN1-3 conditions. The water-use efficiency is higher in the plants grown with CAN1 than those with CAN2-4 at $300 \pm 20 \mu \mathrm{mol} \cdot \mathrm{m}^{-2} \cdot \mathrm{s}^{-1}$. The maximum stomatal aperture was the largest in the plants grown at $300 \pm 20 \mu \mathrm{mol} \cdot \mathrm{m}^{-2} \cdot \mathrm{s}^{-1}$ with CAN1-2 among all plants. Consequently, light levels of $300 \pm 20 \mu \mathrm{mol} \cdot \mathrm{m}^{-2} \cdot \mathrm{s}^{-1}$ in Phalaenopsis Queen Beer 'Mantefon' must be accompanied by nutrient CAN1 to improve photosynthesis and stomatal activity and promote leaf growth under $800 \mu \mathrm{mol} \cdot \mathrm{mol}^{-1} \mathrm{CO}_{2}$ conditions.
\end{abstract}

Keywords: $\mathrm{CO}_{2}$ enrichment; cultivation duration; light intensity; nutrient level; orchid

\section{Introduction}

Phalaenopsis is a genus of epiphytic orchids found mainly in tropical Asia [1,2]. Phalaenopsis Queen Beer 'Mantefon' is an essential plant in Asia, especially China, Japan, and Korea, due to its intense red color flower petals and many small flowers in one flower spike. Many Phalaenopsis species exhibit an obligate CAM pattern characterized by day/night fluctuations of photosynthetic characteristics [3] and nocturnal $\mathrm{CO}_{2}$ absorption [2].

The vegetative growth stage, during which a plant is insensitive to conditions that promote floral initiation [4], varies among different plant species. For Kalanchoe spp., the period of the vegetative growth stage is 44-55 days [5], whereas the average length of the vegetative growth stage in Cymbidium orchid is between 2 and 3 years [6]. Suppose a plant is prematurely exposed to reproductive growth conditions before the end of the vegetative growth stage. In that case, the plant may not support quality flowers and thereby decrease the uniformity of flowering [7]. Vigorous vegetative growth of five leaves and $25 \mathrm{~cm}$ leaf span is desirable to induce flowering in Phalaenopsis [8]. Meeting the minimum leaf formation is important before floral initiation for plant quality [9].

Elevated heating and cooling often generate a large amount of surplus $\mathrm{CO}_{2}$. The surplus $\mathrm{CO}_{2}$ can be used in ornamental greenhouse production by high efficient distributed power generation system [10]. Surplus $\mathrm{CO}_{2}$ enhanced photosynthetic carbon 
assimilation, growth, and flowering of Phalenopsis Queen Beer 'Mantefon' in a commercial greenhouse [11]. The number of leaves, leaf length, and leaf width displayed more significant increases when Phalaenopsis 'Fuller's Pink Swallow' plants were grown under 1600 and $2400 \mu \mathrm{mol} \cdot \mathrm{mol}^{-1} \mathrm{CO}_{2}$ than under $400 \mu \mathrm{mol} \cdot \mathrm{mol}^{-1} \mathrm{CO}_{2}$ [12]. Net $\mathrm{CO}_{2}$ assimilation rate increased in Phalaenopsis Queen Beer 'Mantefon' grown under 800 and $1600 \mu \mathrm{mol} \cdot \mathrm{mol}^{-1}$ $\mathrm{CO}_{2}$ compared to those grown under $400 \mu \mathrm{mol} \cdot \mathrm{mol}^{-1} \mathrm{CO}_{2}$ [13]. Since Phalaenopsis is an ornamental CAM plant, photosynthesis requires $800-1000 \mu \mathrm{mol} \cdot \mathrm{mol}^{-1} \mathrm{CO}_{2}$ to reach normal saturation $[13,14]$. Commercial production of Phalaenopsis cultivated at $800 \mu \mathrm{mol} \cdot \mathrm{mol}^{-1}$ $\mathrm{CO}_{2}$ in a greenhouse, resulting in a significant increase in plant growth and yield of good quality flowers.

The photosynthesis of Phalaenopsis saturates at a light level of 130-180 $\mu \mathrm{mol}$. $\mathrm{m}^{-2} \cdot \mathrm{s}^{-1}[15,16]$. Photoinhibition occurs when plants are exposed to a light level higher than $200 \mu \mathrm{mol} \cdot \mathrm{m}^{-2} \cdot \mathrm{s}^{-1}$ than those to a light level below $125 \mu \mathrm{mol} \cdot \mathrm{m}^{-2} \cdot \mathrm{s}^{-1}$ in Phalaenopsis amabilis (L.) Blume [17] at an ambient $\mathrm{CO}_{2}$ concentration. Naing et al. (2016) [18] suggested the leaf growth rate increased in the plants grown with combined $\mathrm{CO}_{2}$ enrichment, $1000 \mu \mathrm{mol} \cdot \mathrm{mol}^{-1}$ and light level, $250 \mu \mathrm{mol} \cdot \mathrm{m}^{-2} \cdot \mathrm{s}^{-1}$. Similarly, the combined effect improved seedling growth and yield of chrysanthemum [19]. Cho et al. (2019) [20] observed more floral buds and flowers in Phalaenopsis Queen Beer 'Mantefon' when plants were grown under a light level of $260 \pm 40 \mu \mathrm{mol} \cdot \mathrm{m}^{-2} \cdot \mathrm{s}^{-1}$ and $800 \mu \mathrm{mol} \cdot \mathrm{mol}^{-1} \mathrm{CO}_{2}$ than when they were grown under $400 \mu \mathrm{mol} \cdot \mathrm{mol}^{-1} \mathrm{CO}_{2}$.

Phalaenopsis Tam Butterfly plants fertigated with nitrogen $(\mathrm{N})$ concentration of $200 \mathrm{mg} \cdot \mathrm{L}^{-1}$ had a wider leaf spread, produced more and larger leaves, and had greater total leaf areas than those with $\mathrm{N}$ of $100 \mathrm{mg} \cdot \mathrm{L}^{-1}$ [21]. Increasing the $\mathrm{N}$ concentration from 50 to $200 \mathrm{mg} \cdot \mathrm{L}^{-1}$ promoted leaf production in white-flowered Phalaenopsis hybrid [P. amabilis (L.) Blume $\times P$. Mount Kaala 'Elegance'] [22]. Plant photosynthetic responses under enriched $\mathrm{CO}_{2}$ conditions require additional nutrients, including $\mathrm{N}$, phosphorus, and potassium [23-25]. Higher production due to $\mathrm{CO}_{2}$ enrichment increases the nutrient consumption of plants and therefore lowers the salinity level in nutrient solution [26]. Calcium ammonium nitrate (CAN) is a granulated nitrogenous inorganic fertilizer that supplies 25-28\% with the lowest carbon footprint of any fertilizer product [27]. Exogenous calcium (Ca) treatment can increase a plant's tolerance to adverse environments by regulating $\mathrm{N}$ metabolism [28]. Limiting nutrients such as Ca deficiency could reduce shoot dry mass and cause abortion of the apical meristem in Eustoma cultivars [29]. However, the loss of photosynthetic capacity in Phalaenopsis 'Ney Shan Gu Niang' grown at enriched $\mathrm{CO}_{2}$ could be improved by adding $\mathrm{N}$ to the nutrient supply in proportion to the relative growth rate of the plant [30,31].

We examined the effects of the combination of light and CAN levels on the vegetative growth under $800 \mu \mathrm{mol} \cdot \mathrm{mol}^{-1} \mathrm{CO}_{2}$ on the leaf growth, photosynthesis, and chlorophyll a fluorescence and stomatal characteristics of Phalaenopsis Queen Beer 'Mantefon'. This study may provide information for using surplus $\mathrm{CO}_{2}$ in floriculture crop production.

\section{Materials and Methods}

\subsection{Plant Materials and Growth Conditions}

Phalaenopsis Queen Beer 'Mantefon' plants were purchased from Orchid Nursery in Paju, Korea (latitude $37^{\circ} \mathrm{N}$, longitude $\left.126^{\circ} \mathrm{E}\right)$ and transplanted into $10 \mathrm{~cm}$ pots $(0.5 \mathrm{~L}$ container) after 36 weeks of growth. The pots contained 100\% Chilean dried Sphagnum moss (Lonquen, Ltd., Puerto Montt, Chile). Mean temperature, relative humidity, and solar light levels were $29 \pm 2{ }^{\circ} \mathrm{C}, 70 \pm 10 \%$, and $250 \mu \mathrm{mol} \cdot \mathrm{m}^{-2} \cdot \mathrm{s}^{-1}$, respectively. The plants had a mean of 3.6 leaves and a leaf span of $18.3 \mathrm{~cm}$ (longest opposing leaf to a horizontal position).

Purchased plants were moved to the growth chambers (HB-303DHC, Hanbaek Scientific Co., Ltd., Suwon, Korea) of Seoul Women's University (Seoul, Korea) on 18 March 2017, acclimated for two weeks before the treatments. Mean day/night temperatures, 
relative humidity, and daylength were $29 / 25^{\circ} \mathrm{C}, 70 \%$ at constant, and $12 \mathrm{~h}(06: 00-18: 00$ HR), respectively.

Atmospheric $\mathrm{CO}_{2}$ concentrations of the growth chambers were maintained at an ambient concentration (approximately $400 \mu \mathrm{mol} \cdot \mathrm{mol}^{-1} \mathrm{CO}_{2}$ ) from 06:00 to 00:00 $\mathrm{HR}$. The $\mathrm{CO}_{2}$ concentration was enriched during 00:00-06:00 HR, the last $6 \mathrm{~h}$ of the dark period. The $800 \mu \mathrm{mol} \cdot \mathrm{mol}^{-1} \mathrm{CO}_{2}$ was supplied with pure $\mathrm{CO}_{2}$ from compressed gas cylinders (Bottle $\mathrm{CO}_{2} \geq 99.9 \%$ ) (Seoul Specialty Gases Co., Ltd., Seoul, Korea) with $50 \mathrm{~mL} \cdot \mathrm{min}^{-1}$ flow, controlled with an infrared gas analyzer (KCD-HP, Korea Digital, Seoul, Korea) and monitored with a $\mathrm{CO}_{2}$ analyzer (AM-21A, WISE Sensing Inc., Yongin, Korea). The experiment was conducted from 1 April 2017 to 17 January 2018 (40 weeks).

\subsection{The Combination of Light and Calcium Ammonium Nitrogen Levels}

The two-factor design was conducted to determine the effects of the pairwise combinations between light and calcium ammonium nitrogen (CAN) with 22 replicates at each treatment. Eight treatments were configured with the two levels of lights, $150 \pm 20$ and $300 \pm 20 \mu \mathrm{mol} \cdot \mathrm{m}^{-2} \cdot \mathrm{s}^{-1}$, and the four levels of CAN (Table 1) as follows: $150 \pm$ $20 \mu \mathrm{mol} \cdot \mathrm{m}^{-2} \cdot \mathrm{s}^{-1}$ with CAN1 (Control), $150 \pm 20 \mu \mathrm{mol} \cdot \mathrm{m}^{-2} \cdot \mathrm{s}^{-1}$ with CAN2, $150 \pm$ $20 \mu \mathrm{mol} \cdot \mathrm{m}^{-2} \cdot \mathrm{s}^{-1}$ with CAN3, $150 \pm 20 \mu \mathrm{mol} \cdot \mathrm{m}^{-2} \cdot \mathrm{s}^{-1}$ with CAN4, $300 \pm 20 \mu \mathrm{mol} \cdot \mathrm{m}^{-2} \cdot \mathrm{s}^{-1}$ with CAN1, $300 \pm 20 \mu \mathrm{mol} \cdot \mathrm{m}^{-2} \cdot \mathrm{s}^{-1}$ with CAN2, $300 \pm 20 \mu \mathrm{mol} \cdot \mathrm{m}^{-2} \cdot \mathrm{s}^{-1}$ with CAN3, and $300 \pm 20 \mu \mathrm{mol} \cdot \mathrm{m}^{-2} \cdot \mathrm{s}^{-1}$ with CAN4.

Table 1. The total nitrogen $(\mathrm{N})$ concentration, the elements concentrations of calcium (Ca), ammonium $\left(\mathrm{NH}_{4}\right)$, nitrate $\left(\mathrm{NO}_{3}\right)$, phosphate $(\mathrm{P})$, potassium $(\mathrm{K})$, and sulfur $(\mathrm{S})$, electrical conductivity $(\mathrm{EC})$, and $\mathrm{pH}$ as CAN levels.

\begin{tabular}{|c|c|c|c|c|c|c|c|c|c|}
\hline \multirow{2}{*}{ Level } & \multirow{2}{*}{$\begin{array}{l}\text { Total N } \\
\left(\mathrm{mg} \cdot \mathrm{L}^{-1}\right)\end{array}$} & \multicolumn{6}{|c|}{ Elements $\left(\mathrm{mmol} \cdot \mathrm{L}^{-1}\right)$} & \multirow{2}{*}{$\begin{array}{c}\mathrm{EC} \\
\left(\mathrm{dS} \cdot \mathrm{m}^{-1}\right)\end{array}$} & \multirow{2}{*}{$\mathrm{pH}$} \\
\hline & & $\mathrm{Ca}$ & $\mathrm{NH}_{4}$ & $\mathrm{NO}_{3}$ & $\mathbf{P}$ & $\mathbf{K}$ & $S$ & & \\
\hline CAN1 & 200 & 0.90 & 0.55 & 2.97 & 2.74 & 4.37 & 0.81 & $1.6 \pm 0.1$ & 5.9 \\
\hline CAN2 & 400 & 8.63 & 1.11 & 6.05 & 2.74 & 4.37 & 0.81 & $2.1 \pm 0.1$ & 6.0 \\
\hline CAN3 & 600 & 12.80 & 1.72 & 9.13 & 2.74 & 4.37 & 0.81 & $3.0 \pm 0.1$ & 6.1 \\
\hline CAN4 & 800 & 18.80 & 2.27 & 12.20 & 2.74 & 4.37 & 0.81 & $4.9 \pm 0.1$ & 6.1 \\
\hline
\end{tabular}

The light source was three-wave cool white fluorescent lamps (Triband phosphor fluorescent lamps, Dulux L 36 W, Osram Korea Co., Ansan, Korea) and metal halide lamp (MH; GEO-MH 100W-L/P, Geo Lighting, Anseong, Korea), and the photosynthetic photon flux (PPF) was measured using a quantum light meter (3415FSE, Spectrum Technologies Inc., Aurora, IL, USA).

The four CAN levels were adjusted using 0N-52P-35K (Krista MKP, Yara, Oslo, Norway), 12N-61P-0K (Krista MAP, Yara), 11N-0P-0K (Krista MAG, Yara), and 14N0P-46K (Krista K, Yara). Calcium (Ca), ammonium $\left(\mathrm{NH}_{4}\right)$, and nitrate $\left(\mathrm{NO}_{3}\right)$ were 0.90 , 0.55 , and $2.97 \mathrm{mmol} \cdot \mathrm{L}^{-1}$ (CAN1); 8.63, 1.11, and $6.05 \mathrm{mmol} \cdot \mathrm{L}^{-1}$ (CAN2); 12.80, 1.72, and $9.13 \mathrm{mmol} \cdot \mathrm{L}^{-1}$ (CAN3); and 18.80, 2.27, and $12.20 \mathrm{mmol} \cdot \mathrm{L}^{-1}$ (CAN4), respectively (Table 1 ). The levels of total N, electrical conductivity (EC), and $\mathrm{pH}$ of each CAN level were also described in Table 1 . The EC and $\mathrm{pH}$ were measured with a portable EC/pH/TDS meter (HI9811-5, Hanna Instruments, Woonsocket, RI, USA). Each plant was fertigated with $150 \mathrm{~mL}$ of nutrient solution weekly during the experimental period.

\subsection{Measurements of Leaf Growth}

The number of leaves, time to the fifth leaf emergence, and time to the mature leaf span were measured weekly for each plant. The number of leaves with lengths of $\geq 0.5 \mathrm{~cm}$ was measured for each plant every four weeks for 40 weeks. The time to the fifth leaf emergence from the start of the treatments, along with the leaf number above 5 , was measured. The time to the mature leaf span was when the leaf span reached $25 \mathrm{~cm}$. The leaf growth was measured with 13 replicated plants per treatment. 


\subsection{Measurements of Gas Exchange and Chlorophyll a Fluorescence}

Gas exchanges were measured on the uppermost fully opened mature leaf at 20 weeks after treatments (WAT) using a portable photosynthesis system (Li-6400XT, Li-Cor Inc., Lincoln, NE, USA) equipped with an infrared gas analyzer. The leaf temperature was kept at 29 and $25{ }^{\circ} \mathrm{C}$ during the day and night, respectively. Relative humidity in the leaf chamber ranged from $55 \%$ to $70 \%$. The $\mathrm{CO}_{2}$ concentration inside the leaf chamber was maintained at $800 \mu \mathrm{mol} \cdot \mathrm{mol}^{-1} \mathrm{CO}_{2}$, which equals the level in the growth chamber. The net $\mathrm{CO}_{2}$ uptake, water-use efficiency (WUE), stomatal conductance $\left(g_{\mathrm{s}}\right)$, and transpiration rate $\left(t_{\mathrm{r}}\right)$ were measured during 00:00-03:00 HR. The instantaneous WUE was calculated as WUE $=$ net $\mathrm{CO}_{2}$ uptake $/ t_{\mathrm{r}}$ [32]. Gas exchanges were measured with three replicated plants per treatment.

Pulse-amplitude modulated (PAM) fluorometry has become a powerful tool in the study of plant photosynthesis and is increasingly being used for ecological monitoring in situ $[22,33,34]$. Chlorophyll a fluorescence was simultaneously measured on the same leaves used to measure gas exchanges using chlorophyll a fluorometer (JUNIOR PAM, Walz, Effeltrich, Germany) at 20 WAT. The maximum photochemical efficiency (Fv/Fm), representing the energy capture efficiency by open photosystem II (PSII), was estimated after 15 min dark adaptation. The actual quantum yield of PSII $\left(\Phi_{\text {PSII }}\right)$, described as the fraction of absorbed light utilized through photochemistry, and non-photochemical quenching (NPQ) were measured after $15 \mathrm{~min}$ light adaptation at an actinic PPF of $275 \mu \mathrm{mol} \cdot \mathrm{m}^{-2} \cdot \mathrm{s}^{-1}$. Chlorophyll a fluorescence was measured at the middle of the day during 11:00-13:00 HR, considering that $\Phi_{\text {PSII }}$ of Phalaenopsis increased from the sunrise and declined at the end of a day at $12 \mathrm{~h}$ photoperiod in a greenhouse [35]. Chlorophyll a fluorescence was measured with three replicated plants per treatment.

\subsection{Stomatal Aperture Width, Length, Maximum Stomatal Aperture, and Stomatal Index Measurements}

Nail varnish (Shine topcoat, Missha, Korea) was applied to abaxial surfaces of fully expanded leaves, and nail varnish peels were taken from leaves. Cell counts were taken from the broadest area of one leaf, each from at least three replicated plants per treatment. The stomatal aperture width, length, and maximum stomatal apertures were determined by light microscopy (Nikon-YS100, Nikon Co., Tokyo, Japan), using a fitted camera (Smartadapter, AT microscope, Gyeonggi-do, Korea), and measured using ImageJ software v. 1.8.0.

The maximum stomatal aperture $\left(a_{\max }\right)$ was estimated from

$$
a_{\max }=\frac{\pi \times W_{a} \times L_{a}}{4}
$$

where $W_{a}$ is the stomatal aperture width and $L_{a}$ is the stomatal aperture length.

The stomatal index (SI) was estimated from

$$
S I(\%)=\frac{S}{S+E} \times 100
$$

where $S$ is the number of stomata and $E$ is the number of epidermal cells.

\subsection{Statistical Analysis}

Statistical analyses were performed using the SAS system for version 9.4 (SAS Inst., Inc., Cary, NC, USA). Duncan's multiple range test assessed differences among the treatments at $p \leq 0.05$. The graph module analysis was made by SigmaPlot program version 10.0 (Systat Software Inc., San Jose, CA, USA).

\section{Results}

\subsection{Leaf Growth Characteristics}

The number of leaves on the plants grown at $300 \pm 20 \mu \mathrm{mol} \cdot \mathrm{m}^{-2} \cdot \mathrm{s}^{-1}$ conditions was higher than that of $150 \pm 20 \mu \mathrm{mol} \cdot \mathrm{m}^{-2} \cdot \mathrm{s}^{-1}$ at $12-20 \mathrm{WAT}$, regardless of CAN lev- 
els (Figure 1a). The number of leaves was significantly greater in the plants grown at $300 \pm 20 \mu \mathrm{mol} \cdot \mathrm{m}^{-2} \cdot \mathrm{s}^{-1}$ with CAN1 than those grown under control conditions at 24-32 WAT. At 36-40 WAT, the number of leaves was the highest on the plants grown at $300 \pm 20 \mu \mathrm{mol} \cdot \mathrm{m}^{-2} \cdot \mathrm{s}^{-1}$ condition with CAN1 than those grown with CAN2-4 conditions. However, the plants grown at $300 \pm 20 \mu \mathrm{mol} \cdot \mathrm{m}^{-2} \cdot \mathrm{s}^{-1}$ with CAN4 exhibited the lowest leaves appearing at 36-40 WAT.

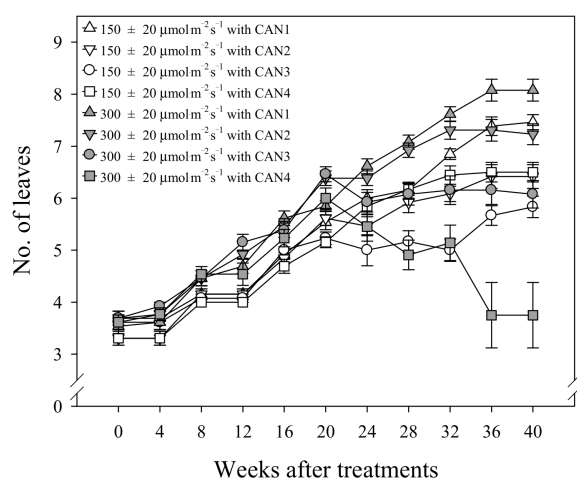

(a)

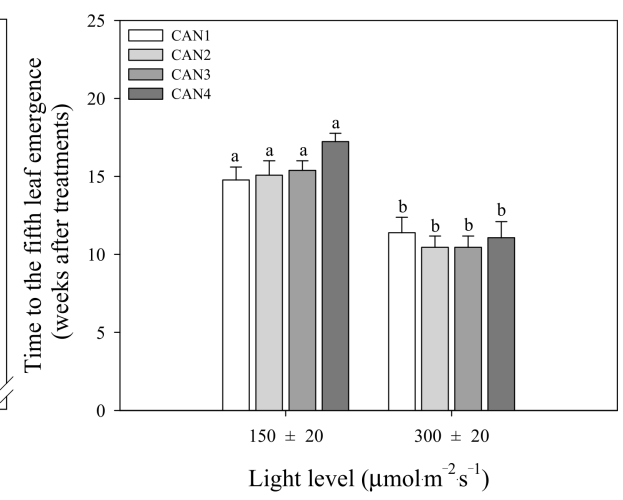

(b)

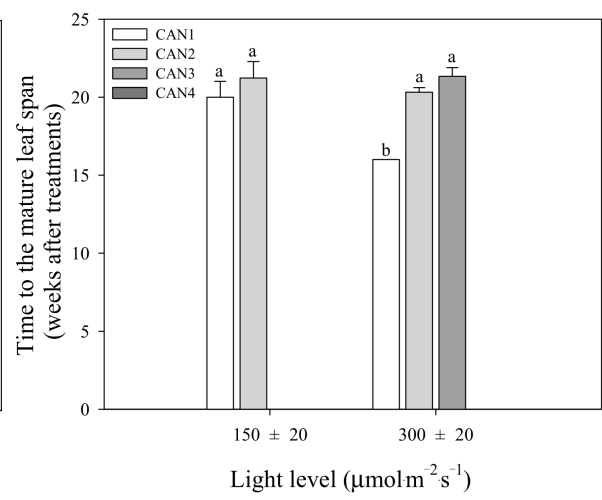

(c)

Figure 1. The number (No.) of leaves (a), time to the fifth leaf emergence (b), and time to the mature leaf span (c) in Phalaenopsis Queen Beer 'Mantefon' grown under two light levels of $150 \pm 20$ and $300 \pm 20 \mu \mathrm{mol} \cdot \mathrm{m}^{-2} \cdot \mathrm{s}^{-1}$ with four calcium ammonium nitrate (CAN) level under $800 \mu \mathrm{mol} \cdot \mathrm{mol}^{-1} \mathrm{CO}_{2}$. The elements concentrations of calcium, ammonium, and nitrate were $0.90,0.55$, and $2.97 \mathrm{mmol} \cdot \mathrm{L}^{-1}$ (CAN1); 8.63, 1.11, and $6.05 \mathrm{mmol} \cdot \mathrm{L}^{-1}$ (CAN2); 12.80, 1.72, and $9.13 \mathrm{mmol} \cdot \mathrm{L}^{-1}$ (CAN3); and 18.80, 2.27, and $12.20 \mathrm{mmol} \cdot \mathrm{L}^{-1}$ (CAN4), respectively. The time to the mature leaf span is based on a $25 \mathrm{~cm}$ leaf span emergence time from any leaf initiation. Vertical bars are standard errors of the means $(n=13)$, and values followed by different letters are significantly different according to Duncan's multiple range test at $p \leq 0.05$.

The plants grown at $300 \pm 20 \mu \mathrm{mol} \cdot \mathrm{m}^{-2} \cdot \mathrm{s}^{-1}$ emerged the fifth leaf within 12 WAT regardless of CAN levels, whereas none of the plants appeared the fifth leaf at $150 \pm 20 \mu \mathrm{mol} \cdot \mathrm{m}^{-2} \cdot \mathrm{s}^{-1}$ conditions within $12 \mathrm{WAT}$ (Figure $1 \mathrm{~b}$ ). The time to the mature leaf span was 20.0,21.2, 16.0, 20.3, and 21.3 WAT, respectively, in the plants grown under control, at $150 \pm 20 \mu \mathrm{mol} \cdot \mathrm{m}^{-2} \cdot \mathrm{s}^{-1}$ with CAN2, and at $300 \pm 20 \mu \mathrm{mol} \cdot \mathrm{m}^{-2} \cdot \mathrm{s}^{-1}$ with CAN13 conditions (Figure 1c). None of the plants had a mature leaf span when they grew at $150 \pm 20 \mu \mathrm{mol} \cdot \mathrm{m}^{-2} \cdot \mathrm{s}^{-1}$ with CAN3-4 and $300 \pm 20 \mu \mathrm{mol} \cdot \mathrm{m}^{-2} \cdot \mathrm{s}^{-1}$ with CAN4 during the experiment (40 weeks) (Figure 1c).

\subsection{Photosynthetic Characteristics}

The net $\mathrm{CO}_{2}$ uptake was significantly greater in the plants grown at $300 \pm$ $20 \mu \mathrm{mol} \cdot \mathrm{m}^{-2} \cdot \mathrm{s}^{-1}$ with CAN1-3 conditions than those grown at $150 \pm 20 \mu \mathrm{mol} \cdot \mathrm{m}^{-2} \cdot \mathrm{s}^{-1}$ with CAN1-3 (Figure 2a). Maximum net $\mathrm{CO}_{2}$ uptake, $4.3 \mu \mathrm{mol} \cdot \mathrm{CO}_{2} \cdot \mathrm{m}^{-2} \cdot \mathrm{s}^{-1}$, showed in the plants grown at $300 \pm 20 \mu \mathrm{mol} \cdot \mathrm{m}^{-2} \cdot \mathrm{s}^{-1}$ with $\mathrm{CAN} 1$ condition. The net $\mathrm{CO}_{2}$ uptake was higher in the plants grown at $300 \pm 20 \mu \mathrm{mol} \cdot \mathrm{m}^{-2} \cdot \mathrm{s}^{-1}$ with CAN1-2 than those grown under control conditions. The decrease of WUE at $300 \pm 20 \mu \mathrm{mol} \cdot \mathrm{m}^{-2} \cdot \mathrm{s}^{-1}$ with CAN1-3 conditions was more apparent in the plants than in the plants grown at $150 \pm 20 \mu \mathrm{mol} \cdot \mathrm{m}^{-2} \cdot \mathrm{s}^{-1}$ with CAN1-3 conditions (Figure $2 \mathrm{~b}$ ). The changes of $g_{\mathrm{s}}$ and $t_{\mathrm{r}}$ did not completely conform to the net $\mathrm{CO}_{2}$ uptake (Figure $2 \mathrm{a}, \mathrm{c}, \mathrm{d}$ ). 


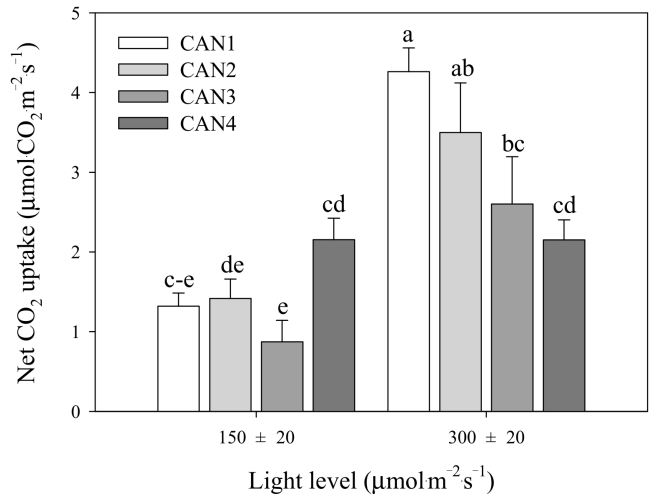

(a)

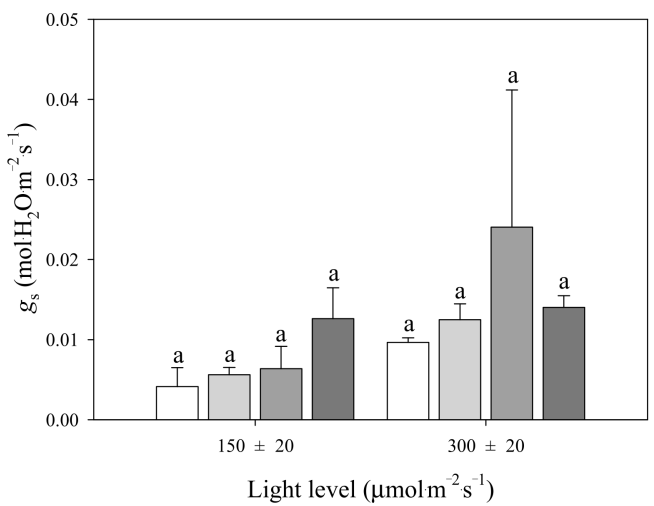

(c)

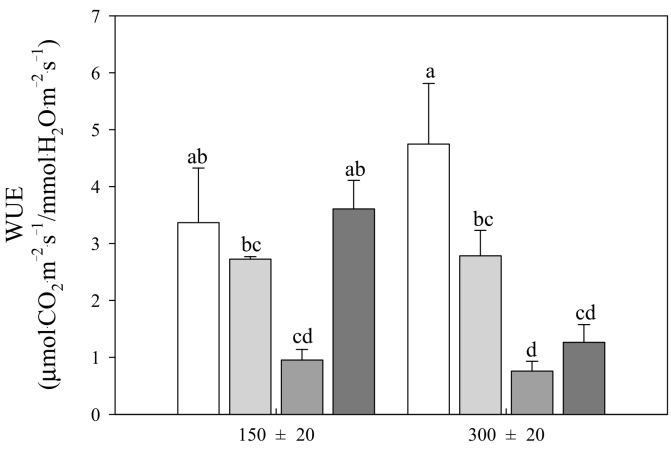

Light level $\left(\mu \mathrm{mol} \cdot \mathrm{m}^{-2} \mathrm{~s}^{-1}\right)$

(b)

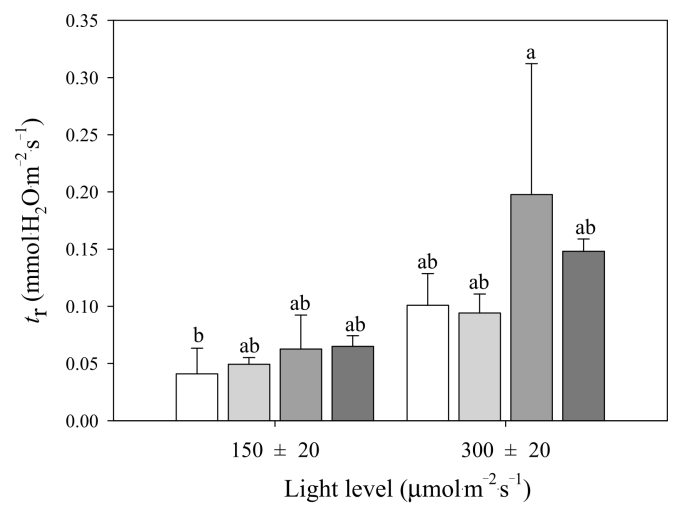

(d)

Figure 2. The net $\mathrm{CO}_{2}$ uptake (a), water-use efficiency (WUE) (b), stomatal conductance $\left(g_{\mathrm{s}}\right)(\mathbf{c})$, and transpiration rate $\left(t_{\mathrm{r}}\right)(\mathbf{d})$ in Phalaenopsis Queen Beer 'Mantefon' grown under two light levels of $150 \pm 20$ and $300 \pm 20 \mu \mathrm{mol} \cdot \mathrm{m}^{-2} \cdot \mathrm{s}^{-1}$ with four calcium ammonium nitrate (CAN) levels under $800 \mu \mathrm{mol} \cdot \mathrm{mol}^{-1} \mathrm{CO}_{2}$. The elements concentrations of calcium, ammonium, and nitrate were $0.90,0.55$, and $2.97 \mathrm{mmol} \cdot \mathrm{L}^{-1}$ (CAN1); 8.63, 1.11, and $6.05 \mathrm{mmol} \cdot \mathrm{L}^{-1}$ (CAN2); $12.80,1.72$, and $9.13 \mathrm{mmol} \cdot \mathrm{L}^{-1}$ (CAN3); and 18.80, 2.27, and $12.20 \mathrm{mmol} \cdot \mathrm{L}^{-1}$ (CAN4), respectively. Measurements were taken at 20 weeks after treatment. Vertical bars are standard errors of the means $(n=3)$, and values followed by different letters are significantly different according to Duncan's multiple range test at $p \leq 0.05$.

\subsection{Chlorophyll a Fluorescence}

The ratios Fv/Fm of dark-adapted samples determine the maximal quantum efficiency of PSII. The values detected on the adaxial surface all appeared to be ranged from $0.617-0.715$ (Table 2), suggesting that all PSII functioned not normally, respective of the light condition of growth. The plants grown at $300 \pm 20 \mu \mathrm{mol} \cdot \mathrm{m}^{-2} \cdot \mathrm{s}^{-1}$ with CAN4 condition had the lowest Fv/Fm. The $\Phi_{\mathrm{PSII}}$ represents a measure of the fraction of absorbed light utilized through photochemistry. The $\Phi_{\mathrm{PSII}}$ was greater in the plants grown at $150 \pm 20 \mu \mathrm{mol} \cdot \mathrm{m}^{-2} \cdot \mathrm{s}^{-1}$ than those with $300 \pm 20 \mu \mathrm{mol} \cdot \mathrm{m}^{-2} \cdot \mathrm{s}^{-1}$ treatments, regardless of CAN levels (Table 2). The NPQ is related to the energy dissipation of the excess radiation to heat in the antenna of PSII in the light-adapted state. There were no significant differences in the NPQ among the treatments (Table 2). 
Table 2. Chlorophyll a fluorescence parameters of the maximal quantum efficiency (Fv/Fm), actual quantum yield of photosystem II ( $\left.\Phi_{\mathrm{PSII}}\right)$, and non-photochemical quenching (NPQ) of chlorophyll a fluorescence in Phalaenopsis Queen Beer 'Mantefon' grown under two light levels of $150 \pm 20$ and $300 \pm 20 \mu \mathrm{mol} \cdot \mathrm{m}^{-2} \cdot \mathrm{s}^{-1}$ with four calcium ammonium nitrate (CAN) levels under $800 \mu \mathrm{mol} \cdot \mathrm{mol}^{-1}$ $\mathrm{CO}_{2}$. The elements concentrations of calcium, ammonium, and nitrate were $0.90,0.55$, and $2.97 \mathrm{mmol} \cdot \mathrm{L}^{-1}$ (CAN1); 8.63, 1.11, and $6.05 \mathrm{mmol} \cdot \mathrm{L}^{-1}$ (CAN2); $12.80,1.72$, and $9.13 \mathrm{mmol} \cdot \mathrm{L}^{-1}$ (CAN3); and 18.80, 2.27, and $12.20 \mathrm{mmol} \cdot \mathrm{L}^{-1}$ (CAN4), respectively.

\begin{tabular}{|c|c|c|c|c|}
\hline $\begin{array}{c}\text { Light Levels } \\
\left(\mu \mathrm{mol} \cdot \mathrm{m}^{-2} \cdot \mathrm{s}^{-1}\right)\end{array}$ & CAN Levels & Fv/Fm & $\Phi_{\text {PSII }}$ & NPQ \\
\hline \multirow[t]{4}{*}{$150 \pm 20$} & CAN1 & $0.709 \pm 0.011 \mathrm{ab}^{\mathrm{z}}$ & $0.299 \pm 0.009 \mathrm{ab}$ & $1.101 \pm 0.084 \mathrm{a}$ \\
\hline & CAN2 & $0.715 \pm 0.001 \mathrm{a}$ & $0.330 \pm 0.025 \mathrm{a}$ & $0.896 \pm 0.189 a$ \\
\hline & CAN3 & $0.697 \pm 0.019 \mathrm{ab}$ & $0.256 \pm 0.016 \mathrm{bc}$ & $1.010 \pm 0.051 \mathrm{a}$ \\
\hline & CAN4 & $0.688 \pm 0.053 \mathrm{ab}$ & $0.251 \pm 0.026 \mathrm{bc}$ & $0.862 \pm 0.089 a$ \\
\hline \multirow[t]{4}{*}{$300 \pm 20$} & CAN1 & $0.647 \pm 0.015 \mathrm{ab}$ & $0.211 \pm 0.018 \mathrm{~cd}$ & $0.835 \pm 0.139 a$ \\
\hline & CAN2 & $0.673 \pm 0.034 \mathrm{ab}$ & $0.230 \pm 0.017 \mathrm{~cd}$ & $0.890 \pm 0.147 a$ \\
\hline & CAN3 & $0.671 \pm 0.021 \mathrm{ab}$ & $0.233 \pm 0.022 \mathrm{~cd}$ & $1.081 \pm 0.032 \mathrm{a}$ \\
\hline & CAN4 & $0.617 \pm 0.030 \mathrm{~b}$ & $0.183 \pm 0.024 \mathrm{~d}$ & $0.839 \pm 0.274 a$ \\
\hline \multicolumn{5}{|c|}{ Significance ${ }^{\mathrm{y}}$} \\
\hline \multicolumn{2}{|c|}{ Light } & * & * & ns \\
\hline \multicolumn{2}{|c|}{ CAN } & ns & ns & ns \\
\hline \multicolumn{2}{|c|}{ Light $\times$ CAN } & ns & ns & ns \\
\hline
\end{tabular}

\subsection{Stomatal Aperture Width, Length, Maximum Stomatal Aperture, and Stomatal Index}

The stomatal aperture width and length were promoted in the plants grown at $300 \pm 20 \mu \mathrm{mol} \cdot \mathrm{m}^{-2} \cdot \mathrm{s}^{-1}$ with CAN1-2 conditions (Table 3 ). This significant promotion of average stomatal aperture width and length might maximize the stomatal aperture (Table 3). There were no significant differences in the stomatal index depending upon light levels. The stomatal index decreased in the plants grown at $150 \pm 20 \mu \mathrm{mol} \cdot \mathrm{m}^{-2} \cdot \mathrm{s}^{-1}$ with CAN2 and those at $300 \pm 20 \mu \mathrm{mol} \cdot \mathrm{m}^{-2} \cdot \mathrm{s}^{-1}$ with CAN3-4 compared to those under control (Table 3).

Table 3. The stomatal aperture width, length, maximum stomatal aperture, and stomatal index in Phalaenopsis Queen Beer 'Mantefon' grown under two light levels of $150 \pm 20$ and $300 \pm 20 \mu \mathrm{mol} \cdot \mathrm{m}^{-2} \cdot \mathrm{s}^{-1}$ with four calcium ammonium nitrate (CAN) levels under $800 \mu \mathrm{mol} \cdot \mathrm{mol}^{-1} \mathrm{CO}_{2}$. The elements concentrations of calcium, ammonium, and nitrate were $0.90,0.55$, and $2.97 \mathrm{mmol} \cdot \mathrm{L}^{-1}$ (CAN1); 8.63, 1.11, and $6.05 \mathrm{mmol} \cdot \mathrm{L}^{-1}$ (CAN2); 12.80, 1.72, and $9.13 \mathrm{mmol} \cdot \mathrm{L}^{-1}$ (CAN3); and 18.80, 2.27, and $12.20 \mathrm{mmol} \cdot \mathrm{L}^{-1}(\mathrm{CAN} 4)$, respectively.

\begin{tabular}{|c|c|c|c|c|c|}
\hline $\begin{array}{c}\text { Light Levels } \\
\left(\mu \mathrm{mol} \cdot \mathrm{m}^{-2} \cdot \mathrm{s}^{-1}\right)\end{array}$ & $\begin{array}{c}\text { CAN } \\
\text { Levels }\end{array}$ & $\begin{array}{c}\text { Stomatal } \\
\text { Aperture Width } \\
(\mu \mathrm{m})\end{array}$ & $\begin{array}{c}\text { Stomatal } \\
\text { Aperture Length } \\
(\mu \mathrm{m})\end{array}$ & $\begin{array}{c}\text { Maximum } \\
\text { Stomatal Aperture } \\
\left(\mu \mathrm{m}^{2}\right)\end{array}$ & $\begin{array}{l}\text { Stomatal } \\
\text { Index } \\
(\%)\end{array}$ \\
\hline \multirow[t]{4}{*}{$150 \pm 20$} & CAN1 & $3.0 \pm 0.4 b^{z}$ & $12.6 \pm 0.6 \mathrm{bc}$ & $27 \pm 5 b$ & $6.23 \pm 0.15 \mathrm{a}$ \\
\hline & CAN2 & $3.3 \pm 0.3 b$ & $12.9 \pm 0.4 b c$ & $29 \pm 3 b$ & $5.07 \pm 0.22 c$ \\
\hline & CAN3 & $2.7 \pm 0.4 b c$ & $14.1 \pm 0.3 \mathrm{ab}$ & $28 \pm 3 b$ & $5.93 \pm 0.28 \mathrm{ab}$ \\
\hline & CAN4 & $1.9 \pm 0.1 \mathrm{c}$ & $13.6 \pm 0.2 \mathrm{bc}$ & $20 \pm 1 b$ & $5.91 \pm 0.10 \mathrm{ab}$ \\
\hline \multirow[t]{4}{*}{$300 \pm 20$} & CAN1 & $5.7 \pm 0.3 \mathrm{a}$ & $13.8 \pm 0.5 \mathrm{ab}$ & $58 \pm 5 a$ & $6.18 \pm 0.26 \mathrm{a}$ \\
\hline & CAN2 & $6.1 \pm 0.5 \mathrm{a}$ & $15.1 \pm 0.5 \mathrm{a}$ & $70 \pm 10 a$ & $5.25 \pm 0.09 \mathrm{bc}$ \\
\hline & CAN3 & $3.0 \pm 0.1 b$ & $11.0 \pm 0.8 \mathrm{~d}$ & $23 \pm 3 b$ & $4.03 \pm 0.55 \mathrm{~d}$ \\
\hline & CAN4 & $3.1 \pm 0.5 b$ & $12.1 \pm 0.5 \mathrm{~cd}$ & $26 \pm 5 b$ & $6.08 \pm 0.16 \mathrm{ab}$ \\
\hline \multicolumn{6}{|c|}{ Significance $^{\mathrm{y}}$} \\
\hline \multicolumn{2}{|c|}{ Light } & $* * *$ & ns & $* * *$ & * \\
\hline \multicolumn{2}{|c|}{ CAN } & $* * *$ & $*$ & $* * *$ & $* * *$ \\
\hline \multicolumn{2}{|c|}{ Light $\times$ CAN } & $* *$ & $* * *$ & $* * *$ & $* *$ \\
\hline
\end{tabular}

${ }^{\mathrm{z}}$ Average values in a column with a different letter are significantly different according to Duncan's multiple range test at $p \leq 0.05(n=3) . \mathrm{y}, *, * *$, and ${ }^{* * *}$ denote significance at $p \leq 0.05, p \leq 0.01$, and $p \leq 0.001$; ns denotes not significant (Duncan's multiple range test). 


\section{Discussion}

Sexual reproduction is delayed until plants reach leaf numbers and sizes (leaf span) sufficient to maintain the energetic demands of flowering. Increasing light level with night interruption increased the number of leaves, leaf length, decreased time to flowering, and improved final plant quality in Cymbidium 'Red Fire' and 'Yokihi' [6]. Compared to plants in the control group, those grown at $300 \pm 20 \mu \mathrm{mol} \cdot \mathrm{m}^{-2} \cdot \mathrm{s}^{-1}$ conditions had more significant numbers of leaves at 24-32 WAT, along with decreased time to the fifth leaf emergence and mature leaf span during the vegetative growth stage (Figure 1). Oh et al. (2008) [36] reported that the sufficient plant growth of 8 leaves and 28 flower numbers in Cyclamen could be achieved by increasing the net $\mathrm{CO}_{2}$ uptake with a light level of $200 \mu \mathrm{mol} \cdot \mathrm{m}^{-2} \cdot \mathrm{s}^{-1}$. Leaf span is increased when either cell expansion or cell division is enhanced [37]. Increased cell division appears to be supported by increased translocate of assimilates and carbohydrate availability in shoot apical meristems [38]. This experiment shows that for Phalaenopsis, increasing light level with CAN1 can be considered a method to promote growth rate than the control plants. This may be because Phalaenopsis Queen Beer 'Mantefon' grown at $300 \pm 20 \mu \mathrm{mol} \cdot \mathrm{m}^{-2} \cdot \mathrm{s}^{-1}$ with CAN1 fixes more large amounts of carbon in photosynthesis than other levels. The net $\mathrm{CO}_{2}$ uptake in the plants grown at $300 \pm 20 \mu \mathrm{mol} \cdot \mathrm{m}^{-2} \cdot \mathrm{s}^{-1}$ with CAN1-3 was 2.5 to 5.5 times greater than those grown at $150 \pm 20 \mu \mathrm{mol} \cdot \mathrm{m}^{-2} \cdot \mathrm{s}^{-1}$ under enriched $\mathrm{CO}_{2}$ conditions (Figure 2a).

Monitoring photochemical efficiency of PSII is considered the most sensitive part of the photosynthetic pathway to plant stress [39]. Pulse-amplitude modulated fluorescence measurements have been used to identify changes in the physiological status of plants in response to changing environments before morphological changes are evident [33]. In nonstressed plants, the Fv / Fm is about $0.77-0.81$ for most plant species [40]. When plants are exposed to stressful conditions, the values of the Fv/Fm drop significantly [41]. Decrease of the Fv/Fm and $\Phi_{\text {PSII }}$ has indicated either down-regulation or recovery of PSII and photoinhibition [32], which adjustments in photochemical capacity can cause the thermal dissipation capacity or both. Decrease in the Fv / Fm due to diurnal photo-inhibition may improve more rapidly in many environments as light levels and $\mathrm{CO}_{2}$ concentration, and nitrogen [42]. Plants are adapted to environments by allocating excessive energy and increasing energy dissipation through the NPQ, which may serve as a photo-protection response [43]. This might be related to the fact that our study site $300 \pm 20 \mu \mathrm{mol} \cdot \mathrm{m}^{-2} \cdot \mathrm{s}^{-1}$ with CAN4 level exceeded the tolerance threshold levels (Table 2), resulting in a decrease in the photochemical efficiency of Phalaenopsis Queen Beer 'Mantefon' under $800 \mu \mathrm{mol} \cdot \mathrm{mol}^{-1}$ $\mathrm{CO}_{2}$.

In commercial production, the ability to schedule potted Phalaenopsis to flower during periods of high energy cost is desirable because it allows precise ornamental plants ${ }^{\prime}$ scheduling and improves production efficiency. $\mathrm{CO}_{2}$ enrichment allows Phalaenopsis to continue to initiate leaf. Enriched $\mathrm{CO}_{2}$ of $800-1600 \mu \mathrm{mol} \cdot \mathrm{mol}^{-1}$ promoted the leaf growth and net $\mathrm{CO}_{2}$ uptake in many Phalaenopsis, including 'Fuller's Pink Swallow' [12], 'Ney Shan Gu Niang' [30], and Queen Beer 'Mantefon' [13,14]. According to Lin and Tsu (2004) [17], the threshold light level for photosynthesis and starch accumulation in Phalaenopsis amabilis (L.) Blume was $<200 \mu \mathrm{mol} \cdot \mathrm{m}^{-2} \cdot \mathrm{s}^{-1}$. Only the plants were flowered when they were grown at $260 \pm 40 \mu \mathrm{mol} \cdot \mathrm{m}^{-2} \cdot \mathrm{s}^{-1} \mathrm{compared}$ to that grown at $90 \pm 10 \mu \mathrm{mol} \cdot \mathrm{m}^{-2} \cdot \mathrm{s}^{-1}$ under $\mathrm{CO}_{2}$ of $800 \mu \mathrm{mol} \cdot \mathrm{mol}^{-1}$ conditions in Phalaenopsis Queen Beer 'Mantefon' [20]. In the present study, leaf emergence is fastened in the plants grown at $300 \pm 20 \mu \mathrm{mol} \cdot \mathrm{m}^{-2} \cdot \mathrm{s}^{-1}$ along with $800 \mu \mathrm{mol} \cdot \mathrm{mol}^{-1} \mathrm{CO}_{2} \mathrm{compared}$ to that grown at $150 \pm 20 \mu \mathrm{mol} \cdot \mathrm{m}^{-2} \cdot \mathrm{s}^{-1}$, regardless of CAN level (Figure 1b). Shortening the fifth leaf emergence can be promoted flowering [8].

Stomatal morphogenesis and behavior are controlled by genetic and environmental factors such as light $[44,45]$ and $\mathrm{CO}_{2}$ enrichment [46]. The status of stomata governs the overall net $\mathrm{CO}_{2}$ uptake and WUE from plants [45]. The fine regulation of opening and closure of stomata in response to light and nutrients is crucial to ornamental crop production. The increase of stomatal aperture length and width and maximum stomatal aperture indicated a rise in overall stomatal pore area through the regulations of membrane 
transport of guard cells [45]. The stomatal index represents the ratio of the number of stomata to the number of stomata and epidermal cells per unit leaf area, serving as a sensitive parameter detecting stomatal frequency changes [47]. Increasing light levels from 90 to $250 \mu \mathrm{mol} \cdot \mathrm{m}^{-2} \cdot \mathrm{s}^{-1}$ increased tobacco leaf stomatal aperture length and stomatal index. An increase in the stomatal aperture with increasing light level from 10\% sunlight to full sunlight has also been previously noted in two Eucalyptus globulus ssp. [48]. The larger stomata in $200 \mu \mathrm{mol} \cdot \mathrm{m}^{-2} \cdot \mathrm{s}^{-1}$ provide higher $\mathrm{CO}_{2}$ intake and enhanced leaf cooling through transpiration water loss [49]. The plants have adapted to certain light levels by maintaining low or high stomatal index [45]. Here, Phalaenopsis Queen Beer 'Mantefon' stomata showed an increased response to the light level of $300 \pm 20 \mu \mathrm{mol} \cdot \mathrm{m}^{-2} \cdot \mathrm{s}^{-1}$ with CAN1-2 by significantly increasing the stomatal aperture width and length (Table 3 ). Those findings indicated that the stomatal aperture might be a critical determinant for photosynthesis and Phalaenopsis Queen Beer 'Mantefon' leaf growth.

The enriched $\mathrm{CO}_{2}$ increased plant growth only when there was high nutrient availability $[23,24]$. Adding Ca fertilizer can promote plant growth and significantly increase plant yield in tomatoes [50] and cucumber and melon [51]. This may be connected with the findings that Ca promotes N's absorption by plants, increases $\mathrm{NO}_{3}$ enzyme activity in the leaf, and enhances plant photosynthetic capacity $[50,52]$. But ${ }^{15} \mathrm{~N}$ tracer of $\mathrm{N}$ results confirmed that rising of $\mathrm{Ca}$ levels forms antagonistic effects under high levels, affecting $\mathrm{N}$ absorption, distribution, or utilization in plants, and finally influencing the plant growth of apples [52]. $\mathrm{Ca}$ and $\mathrm{N}$ added into irrigation water can significantly improve the plant growth, fruit yield, and membrane permeability affected by high salinity and can also correct both $\mathrm{Ca}$ and $\mathrm{N}$ deficiencies in tomato and pepper fruit [53]. However, the lowest ${ }^{15} \mathrm{~N}$ absorption was observed in Ca-free treatment, and the highest uptake was under $6 \mathrm{mmol} \cdot \mathrm{L}^{-1} \mathrm{Ca}$ supply [52]. In the present study, the WUE of the plants grown at $300 \pm 20 \mu \mathrm{mol} \cdot \mathrm{m}^{-2} \cdot \mathrm{s}^{-1}$ with CAN1 condition was approximately $41-73 \%$ greater than those grown with CAN2-4 conditions at the same light level (Figure 2b). Water use decreased when saline water was used [53]. Sonneveld and Voogt (1999) [51] have reported that the WUE in tomatoes was reduced with high $\mathrm{NaCl}$. A moderate Ca fertilizer supply of CAN1 consisting of $0.90 \mathrm{mmol} \cdot \mathrm{L}^{-1}$ is crucial to ensure better growth and improve $\mathrm{N}$ absorption in the plants.

\section{Conclusions}

Plants grown at $300 \pm 20 \mu \mathrm{mol} \cdot \mathrm{m}^{-2} \cdot \mathrm{s}^{-1}$ with CAN1 should have vigorous vegetative growth that will rapidly attain the minimum leaf size required for flowering and have leaves greater in number than those grown under control conditions and all the plants grown with CAN2-4. In this study, $300 \pm 20 \mu \mathrm{mol} \cdot \mathrm{m}^{-2} \cdot \mathrm{s}^{-1}$ with CAN1 condition increased Phalaenopsis net $\mathrm{CO}_{2}$ uptake and maximum stomatal aperture. This data suggest that crop time can be decreased when the light level of $300 \pm 20 \mu \mathrm{mol} \cdot \mathrm{m}^{-2} \cdot \mathrm{s}^{-1}$ with CAN1 consisting of $0.90 \mathrm{mmol} \cdot \mathrm{L}^{-1} \mathrm{Ca}, 0.55 \mathrm{mmol} \cdot \mathrm{L}^{-1} \mathrm{NH}_{4}$, and $2.97 \mathrm{mmol} \cdot \mathrm{L}^{-1} \mathrm{NO}_{3}$ for Phalaenopsis cultivation than the control conditions. Consequently, light levels of $300 \pm 20 \mu \mathrm{mol} \cdot \mathrm{m}^{-2} \cdot \mathrm{s}^{-1}$ in Phalaenopsis Queen Beer 'Mantefon' must be accompanied by nutrient CAN1 to improve the photosynthesis and stomatal activity and promote the leaf growth under $800 \mu \mathrm{mol} \cdot \mathrm{mol}^{-1}$ $\mathrm{CO}_{2}$ condition.

Author Contributions: Conceptualization, A.R.C. and Y.J.K.; methodology, A.R.C., S.W.C. and Y.J.K.; validation, A.R.C., S.W.C. and Y.J.K.; formal analysis, A.R.C. and S.W.C.; investigation, A.R.C.; writing - original draft preparation, A.R.C., S.W.C. and Y.J.K.; writing—review and editing, S.W.C. and Y.J.K.; visualization, A.R.C. and Y.J.K.; supervision, Y.J.K.; project administration, Y.J.K.; funding acquisition, Y.J.K. All authors have read and agreed to the published version of the manuscript.

Funding: This research was funded by the National Research Foundation of Korea, grant number "NRF-2018R1A2B6007834" and Seoul Women's University "2021-0104".

Institutional Review Board Statement: Not applicable.

Informed Consent Statement: Not applicable. 
Conflicts of Interest: The authors declare no conflict of interest.

\section{References}

1. Tsai, C.C. Molecular Phylogeny and Biogeography of Phalaenopsis Species; World Scientific: Singapore, 2011; pp. 1-24.

2. Guo, W.J.; Lin, Y.Z.; Lee, N. Photosynthetic light requirements and effects of low irradiance and daylength on Phalaenopsis amabilis. J. Am. Soc. Hortic. Sci. 2012, 137, 465-472. [CrossRef]

3. Liu, Y.C.; Liu, C.H.; Lin, Y.C.; Lu, C.H.; Chen, W.H.; Wang, H.L. Effect of low irradiance on the photosynthetic performance and spiking of Phalaenopsis. Photosynthetica 2016, 54, 259-266. [CrossRef]

4. Bernier, G.; Kinet, J.M.; Sachs, R.M. Control by Nutrition and Water Stress; CRC Press: Boca Raton, FL, USA, 1981; pp. 13-20.

5. Huang, C.H.; Chu, C.Y. The flower development and photoperiodism of native Kalanchoe spp. in Taiwan. Sci. Hortic. 2012, 146, 59-64. [CrossRef]

6. Kim, Y.J.; Lee, H.J.; Kim, K.S. Night interruption promotes vegetative growth and flowering of Cymbidium. Sci. Hortic. 2011, 130, 887-893. [CrossRef]

7. Cameron, A.; Yuan, M.; Heins, R.; Carlson, W. Juvenility: Your perennial crop's age affects flowering. GrowerTalks 1996, 60, 30-32.

8. Blanchard, M.; Lopez, R.; Runkle, E.; Wang, Y.T.; Lopez, R. Growing the best Phalaenopsis. Orchids 2007, 4, $266-271$.

9. Purvis, O.N. An analysis of the influence of temperature during germination on the subsequent development of certain winter cereals and its relation to the effect of length of day. Ann. Bot. 1934, 48, 919-955. [CrossRef]

10. Lee, S.M.; Lee, Y.D.; Kim, S.Y.; Kim, C.U.; Park, K.S. Study on GHP-based integrated energy generation system for horticulture. Korean Soc. Agric. Mach. 2015, 20, 393-394.

11. Cho, A.R.; Choi, S.H.; Kim, Y.J. Flowering and photosynthetic responses of Phalaenopsis under elevated $\mathrm{CO}_{2}$ and nutrient supply. Hortic. Sci. Technol. 2020, 38, 595-607.

12. Kim, H.J.; Cho, A.R.; Park, K.S.; Kim, Y.J. Effect of $\mathrm{CO}_{2}$ enrichment on growth and flowering of Phalaenopsis. Hortic. J. 2017, 86, 389-394.

13. Yun, D.L.; Kim, H.J.; Kim, Y.J. $\mathrm{CO}_{2}$ enrichment increased leaf initiation and photosynthesis in Doritaenopsis Queen Beer 'Mantefon' orchids. Hortic. Environ. Biotechnol. 2018, 59, 159-165. [CrossRef]

14. Song, S.J.; Yun, D.L.; Cho, A.R.; Kim, Y.J. Photosynthetic and growth response of Phalaenopsis Queen Beer 'Mantefon' to variable $\mathrm{CO}_{2}$ concentrations at different vegetative growth stages. Flower Res. J. 2019, 27, 9-16. [CrossRef]

15. Ota, K.; Morioka, K.; Yamamoto, Y. Effects of leaf age, inflorescence, temperature, light intensity and moisture conditions on CAM photosynthesis in Phalaenopsis. J. Jpn. Soc. Hortic. Sci. 1991, 60, 125-132. [CrossRef]

16. Lootens, P.; Heursel, J. Irradiance, temperature, and carbon dioxide enrichment affect photosynthesis in Phalaenopsis hybrids HortScience 1998, 33, 1183-1185. [CrossRef]

17. Lin, M.J.; Hsu, B.D. Photosynthetic plasticity of Phalaenopsis in response to different light environments. J. Plant Physiol. 2004, 161, 1259-1268. [CrossRef] [PubMed]

18. Naing, A.H.; Jeon, S.M.; Park, J.S.; Kim, C.K. Combined effects of supplementary light and $\mathrm{CO}_{2}$ on rose growth and the production of good quality cut flowers. Can. J. Plant Sci. 2016, 96, 503-510. [CrossRef]

19. Mortensen, L.M.; Moe, R. Growth responses of some greenhouse plants to environment. V. Effect of CO2, O2 and light on net photosynthetic rate in Chrysanthemum morifolium Ramat. Sci. Hortic. 1983, 19, 133-140. [CrossRef]

20. Cho, A.R.; Song, S.J.; Chung, S.W.; Kim, Y.J. $\mathrm{CO}_{2}$ enrichment with higher light level improves flowering quality of Phalaenopsis Queen Beer 'Mantefon'. Sci. Hortic. 2019, 247, 356-361. [CrossRef]

21. Wang, Y.T. Effects of six fertilizers on vegetative growth and flowering of Phalaenopsis orchids. Sci. Hortic. 1996, 65, 191-197. [CrossRef]

22. Wang, Y.T.; Gregg, L.L. Medium and fertilizer affect the performance of Phalaenopsis orchids during two flowering cycles. HortScience 1994, 29, 269-271. [CrossRef]

23. Prior, S.A.; Runion, G.B.; Mitchell, R.J.; Rogers, H.H.; Amthor, J.S. Effects of atmospheric $\mathrm{CO}_{2}$ on longleaf pine: Pproductivity and allocation as influenced by nitrogen and water. Tree Physiol. 1997, 17, 397-405. [CrossRef] [PubMed]

24. Reddy, K.R.; Zhao, D. Interactive effects of elevated $\mathrm{CO}_{2}$ and potassium deficiency on photosynthesis, growth, and biomass partitioning of cotton. Field Crops Res. 2005, 94, 201-213. [CrossRef]

25. Seneweera, S.P.; Conroy, J.P. Growth, grain yield and quality of rice (Oryza sativa L.) in response to elevated CO2 and phosphorus nutrition. Soil Sci. Plant Nutr. 1997, 43, 1131-1136. [CrossRef]

26. Sánchez-Guerrero, M.C.; Lorenzo, P.; Medrano, E.; Baille, A.; Castilla, N. Effects of EC-based irrigation scheduling and CO 2 enrichment on water use efficiency of a greenhouse cucumber crop. Agric. Water Manag. 2009, 96, 429-436. [CrossRef]

27. Thyssenkrupp. 2019. Available online: https://insights.thyssenkrupp-industrial-solutions.com/story/ammonium-nitratefertilizer-and-why-it-is-the-preferred-choice-of-european-farmers / (accessed on 9 December 2021).

28. Gao, H.; Jia, Y.; Guo, S.; Lv, G.; Wang, T.; Juan, L. Exogenous calcium affects nitrogen metabolism in root-zone hypoxia-stressed muskmelon roots and enhances short-term hypoxia tolerance. J. Plant Physiol. 2011, 168, 1217-1225. [CrossRef]

29. Chen, C.T.; Lee, C.L.; Yeh, D.M. Effects of nitrogen, phosphorus, potassium, calcium, or magnesium deficiency on growth and photosynthesis of Eustoma. HortScience 2018, 53, 795-798. [CrossRef]

30. Xu, S.; Yuan, X.; Zhang, Y.; Ye, Q. Effect of elevated $\mathrm{CO}_{2}$ combined with two nitrogen levels on photosynthesis, growth and leaf structure in cam orchid Phalaenopsis sp. Int. J. Agric. Biol. 2019, 22, 882-890. 
31. Farage, P.K.; McKee, I.F.; Long, S.P. Does a low nitrogen supply necessarily lead to acclimation of photosynthesis to elevated $\mathrm{CO}_{2}$ ? Plant Physiol. 1998, 118, 573-580. [CrossRef]

32. Xu, S.; Zhu, X.; Li, C.; Ye, Q. Effects of $\mathrm{CO}_{2}$ enrichment on photosynthesis and growth in Gerbera jamesonii. Sci. Hortic. 2014, 177, 77-84. [CrossRef]

33. Zha, T.S.; Wu, Y.J.; Jia, X.; Zhang, M.Y.; Bai, Y.J.; Liu, P.; Ma, J.Y.; Bourque, C.P.-A.; Peltola, H. Diurnal response of effective quantum yield of PSII photochemistry to irradiance as an indicator of photosynthetic acclimation to stressed environments revealed in a xerophytic species. Ecol. Indic. 2017, 74, 191-197. [CrossRef]

34. Wang, Y.T.; Chang, Y.C.A. Effects of nitrogen and the various forms of nitrogen on Phalaenopsis orchid-A review. HortTechnology 2017, 27, 144-149. [CrossRef]

35. Pollet, B.; Steppe, K.; Van Labeke, M.-C.; Lemeur, R. Diurnal cycle of chlorophyll fluorescence in Phalaenopsis. Photosynthetica 2009, 47, 309-312. [CrossRef]

36. Oh, W.; Rhie, Y.H.; Park, J.H.; Runkle, E.S.; Kim, K.S. Flowering of cyclamen is accelerated by an increase in temperature, photoperiod, and daily light integral. J. Hortic. Sci. Biotechnol. 2008, 83, 559-562. [CrossRef]

37. Pritchard, S.G.; Rogers, H.H.; Prior, S.A.; Peterson, C.M. Elevated $\mathrm{CO}_{2}$ and plant structure: a review. Glob. Chang. Biol. 1999, 5, 807-837. [CrossRef]

38. Kinsman, E.A.; Lewis, C.; Davies, M.S.; Young, J.E.; Francis, D.; Vilhar, B.; Ougham, H.J. Elevated $\mathrm{CO}_{2}$ stimulates cells to divide in grass meristems: A differential effect in two natural populations of Dactylis glomerata. Plant Cell Environ. 1997, 20, 1309-1316. [CrossRef]

39. Becker, D.W.; Bain, G.; Norman, J.; Moholt-Siebert, M. Two Sites of Heat-Induced Damage to Photosystem II; Springer: Berlin/Heidelberg, Germany, 1990; pp. 3499-3502.

40. Björkman, O.; Demmig, B. Photon yield of $\mathrm{O}_{2}$ evolution and chlorophyll fluorescence characteristics at $77 \mathrm{~K}$ among vascular plants of diverse origins. Planta 1987, 170, 489-504. [CrossRef]

41. Krause, G.H.; Winter, K. Photoinhibition of photosynthesis in plants growing in natural tropical forest gaps. A chlorophyll fluorescence study. Bot. Acta 1996, 109, 456-462.

42. Ač, A.; Malenovský, Z.; Olejníčková, J.; Gallé, A.; Rascher, U.; Mohammed, G. Meta-analysis assessing potential of steady-state chlorophyll fluorescence for remote sensing detection of plant water, temperature and nitrogen stress. Remote Sens. Environ. 2015, 168, 420-436. [CrossRef]

43. Wu, Y.J.; Zha, T.S.; Jia, X.; Qin, S.G.; Li, Y.; Wang, B. Temporal variation and controlling factors of photochemical efficiency and non-photochemical quenching in Artemisia ordosica. Chin. J. Ecol. 2015, 34, 319-325.

44. Lake, J.A.; Quick, W.; Beerling, D.J.; Woodward, F.I. Signals from mature to new leaves. Nature 2001, 411, 154. [CrossRef]

45. O'Carrigan, A.; Hinde, E.; Lu, N.; Xu, X.-Q.; Duan, H.; Huang, G.; Mak, M.; Bellotti, B.; Chen, Z.H. Effects of light irradiance on stomatal regulation and growth of tomato. Environ. Exp. Bot. 2014, 98, 65-73. [CrossRef]

46. Uprety, D.C.; Dwivedi, N.; Jain, V.; Mohan, R. Effect of elevated carbon dioxide concentration on the stomatal parameters of rice cultivars. Photosynthetica 2002, 40, 315-319. [CrossRef]

47. Dilcher, D.L.; Kuerschner, W.M.; Visscher, H.; Wagner, F. Fossil leaves as biosensors of eocene paleoatmospheric $\mathrm{CO}_{2}$. Environ Geosci. 1999, 6, 151-152. [CrossRef]

48. James, S.A.; Bell, D.T. Influence of light availability on leaf structure and growth of two Eucalyptus globulus ssp globulus provenances. Tree Physiol. 2000, 20, 1007-1018. [CrossRef]

49. Fanourakis, D.; Hyldgaard, B.; Giday, H.; Aulik, I.; Bouranis, D.; Körner, O.; Ottosen, C. Stomatal anatomy and closing ability is affected by supplementary light intensity in rose (Rosa hybrida L.). Hortic. Sci. 2019, 46, 81-89. [CrossRef]

50. Saure, M.C. Why calcium deficiency is not the cause of blossom-end rot in tomato and pepper fruit-a reappraisal. Sci. Hortic. 2014, 174, 151-154. [CrossRef]

51. Sonneveld, C.; De Kreij, C. Response of cucumber (Cucumis sativus L.) to an unequal distribution of salts in the root environment Plant Soil 1999, 209, 47-56. [CrossRef]

52. Xing, Y.; Zhu, Z.L.; Wang, F.; Zhang, X.; Li, B.Y.; Liu, Z.X.; Wu, X.X.; Ge, S.F.; Jiang, Y.M. Role of calcium as a possible regulator of growth and nitrate nitrogen metabolism in apple dwarf rootstock seedlings. Sci. Hortic. 2021, 276, 109740. [CrossRef]

53. Kaya, C.; Higgs, D.; Kirnak, H.; Tas, I. Ameliorative effect of calcium nitrate on cucumber and melon plants drip irrigated with saline water. J. Plant Nutr. 2003, 26, 1665-1681. [CrossRef] 